\title{
POST-DISASTER CONSTRUCTION \& DEMOLITION DEBRIS MANAGEMENT: A SRI LANKA CASE STUDY
}

\author{
Gayani Karunasena ${ }^{1}$, Dilanthi Amaratunga ${ }^{2}$, Richard Haigh ${ }^{3}$ \\ ${ }^{1}$ Department of Building Economics, University of Moratuwa, Katubedda, Moratuwa, Sri Lanka \\ ${ }^{2,3}$ School of the Built Environment, University of Salford, 4th Floor, \\ Maxwell Building the Crescent, Salford, Greater Manchester M5 4WT, UK \\ E-mails: ${ }^{1}$ gayani@becon.mrt.ac.lk (corresponding author); ${ }^{2}$ r.d.g.amaratunga@salford.ac.uk; \\ r.p.haigh@salford.ac.uk \\ Received 29 Jul. 2010; accepted 07 Mar. 2011
}

\begin{abstract}
The increasing nature of impacts from disasters has made post disaster management a key area of concern. The management of disaster waste is revealed as an area of least concern yet it presents momentous challenges for those with inadequate capacities due to the large volume and hazardous constituents created, specifically in developing countries. This paper aims to report the findings of post-disaster waste management strategies and challenges identified in Sri Lanka. Data was gathered through interviews with government and non-government organisations at national and local level. The lack of an established hierarchy and single point of responsibility, mandatory and enforceable rules and regulations; inadequate capacity and funds, and lack of communication and coordination were identified as gaps in post-disaster waste management. This enabled the identification of post-disaster waste management strategies, highlighting gaps that need to be addressed for effective C\&D debris management for Sri Lanka's future resilience.
\end{abstract}

Keywords: construction and demolition debris, disaster waste, post-disaster, Sri Lanka, waste management strategies.

\section{Introduction}

The world has witnessed massive destruction caused by disasters which are occurring with increasing frequency worldwide with devastating impact (Shaw 2006). These have had a disproportionately heavy toll on developing countries both in terms of loss of lives and damage to property (Ofori 2002). Specifically, the threat of natural disasters is expected to grow with greater frequency and intensity in future due to climate change (Helmer, Hihorst 2006; Barnett 2007; Salehyan 2008). In addition, poverty, population growth, rapid urbanization, lack of public awareness and information concerning disaster-riskreduction, changes in cultural practices, environmental degradation, war and civil strife are highlighted as the main causes contributing to disasters.

The different types of impacts from disasters, such as deaths, injured and misplaced people, property damage, collapsing buildings, infrastructure and crop destruction are some of the critical reasons (Lindell, Prater 2003; Shaw 2006) which lead to the creation of tremendous amounts of disaster waste. Pike (2007) argues that a significant portion of cost of disasters is spent on recovery and reconstruction, including debris management. For example, according to the U.S. Federal Emergency Management Agency (FEMA), approximately $55 \%$ of all federal disaster spending is directed toward immediate relief, including debris removal (Pike 2007).

Managing disaster waste becomes further critical as, unlike ordinary waste, it is mixed (Kobayashi 1995) and may be contaminated with certain toxic or hazardous constituents that lead to environmental degradation and health problems (Brown et al. 2010). Thus, ineffective management of disaster waste can lay the foundations for serious environmental and economic problems in a country. These problems are equally applicable in Sri Lanka as it is prone to frequent natural disasters. Specifically, the United Nations Environment Protection Report (2005) states that debris generated by the Asian Tsunami of December $26^{\text {th }} 2004$ was not properly disposed of, reused or managed (UNEP 2005b). Hence, in Sri Lanka there is a significant necessity to evaluate disaster waste management strategies adopted during post-disasters in recent years. Therefore, this paper aims to explore post-disaster waste management strategies adopted and the challenges faced at both national and local level in Sri Lanka. The next section of the paper reports the findings revealed through a review of the literature on post-disaster waste management, globally and locally.

\section{Post-disaster waste management: $C \& D$ debris}

In a disaster, the generation of waste is unavoidable. According to the California code of regulation 17210.1(d) of title 14, disaster waste means "nonhazardous solid waste caused by or directly related to disaster". Petersen (2004) indicates that disaster waste becomes critical as it differs from the normal situation that generates waste in more or less stable quantities and composition whereas in a postdisaster situation, it radically changes in type and quanti- 
ty. Further, disaster waste may contain or be contaminated with certain toxic or hazardous constituents. In 2008, the Environment Protection Agency in the USA identified several items generated as waste from post-disaster situations such as soil and sediment, building rubble, vegetation, personal effects, hazardous materials, mixed domestic and clinical waste and often, human and animal remains, representing a risk to human health from biological, chemical and physical sources (EPA 2008).

Literature revealed approximate quantities of disaster waste generated from disasters in large volume such as the Haiti earthquake in 2010 (23-60 million tons), the Sichuan earthquake in 2008 (20 million tons), Hurricane Katrina in 2005 (76 million cubic meters), the Marmara earthquake in 1999 (13 million tons), the Kosovo earthquake in 1999 (10 million tons) and 20 million tons from the Kobo earthquake in Japan in 1995 (Lauritzen 1998; Ardani et al. 2009; Baycan, Petersen 2002; Zeilinga de Boer, Sanders 2004; Kuramoto 1996; Shaw, Goda 2004; Baycan 2004; Taylor 2008; Booth 2010). However, a report on managing disaster debris by Luther (2008) indicated that it is necessary to estimate the total volume of debris to manage disaster waste appropriately as it provides for the prior identification of appropriate staging grounds to separate waste, for necessary landfill space, for relevant contract services and anticipated special handling requirements applicable to hazardous debris.

Pike (2007) indicates that disaster debris management commences immediately following a disaster and continues during long term reconstruction. Many authors have discussed the phenomena of debris management during post-disaster reconstruction (Davis 1978; OliverSmith 1990). The first phase of debris management is dedicated to immediate disaster relief, focused on removing debris from access routes, and residential and commercial areas by the government agencies in collaboration with non government agencies. The second phase of debris management is the long-term removal of debris, which assists reconstruction and adopts strategies to counter future threats to human health or environment (Blakely 2007). The literature on waste management strategies and models has revealed that developed countries which experience frequent disasters have directed technological know-how and expertise towards successful implementation of disaster debris management, such as the Marmara earthquake in Turkey in 1999 (Baycan 2004), the Kobo earthquake in Japan in 1995 (Eerland 1995), and the Northridge Earthquake in the USA in 1994 (EPA 1995).

Waste management represents a major environmental issue in any post-disaster scenario. Specifically, C\&D debris when it is contaminated with toxic substances such as lead asbestos becomes hazardous, which leads to environmental degradation and health problems (Pelling et al. 2002). Thus, measures aimed at controlling disaster waste generation such as building regulations and codes are needed at the mitigation phase of disaster management. Many researchers have emphasized the importance of designing early-stage strategies to be managed in the most environmentally sound manner possible, maxi- mizing source reduction and recycling options, and minimizing land disposal (Lauritzen 1998; Baycan, Petersen, 2002; Brown et al. 2010). Many authors have highlighted that disaster debris can severely impact on emergency response and recovery effort (Rafee et al. 2008; UNEP 2005c; Brown, Milke 2009; Brown et al. 2010). Petersen (2004) points out further adverse effects on water quality, air quality and noise, flora and fauna, visual impacts and socio economic impacts arising from post-disaster waste management. For example, Srinivas and Nakagawa (2007) also indicate that solid waste and disaster debris are the most critical environmental problem faced by countries affected by the tsunami in 2004 . According to the author, disposing the waste in an environmentally friendly manner and recycling waste have been identified as critical issues. Further UNEP reports (2005a, b, c) highlight the extensive damage caused in Sri Lanka, the Maldives and Indonesia, on environmental infrastructures. Further, the General Accounting Office Report on "Hurricane Katrina: Continuing debris removal and disposal issues" also highlighted how failures in disaster debris management continue to impact on the environmental health of citizens three years later (GAO 2008). A Rapid Environment Impact Assessment conducted after the Haiti Earthquake of 2010 also highlighted the importance of proper debris management to avoid damage to the environment, livelihoods and recovery efforts (Kelly 2010). A report on managing disaster debris by Luther (2008) indicated many challenges in managing disaster debris, such as issues associated with managing large volumes of waste, ensuring property owners are able to return to an area and assist with the clean-up operation, separating hazardous and non-hazardous waste, and managing asbestos-contaminated waste. In addition, the literature reveals demolition, the establishment of permanent recycling infrastructure and the enhancement of eco-industrial networks through strategic planning as some of the key barriers in C\&D debris management (Baycan, Petersen 2002; Zeilinga de Boer, Sanders 2004; Ardani et al. 2009). Ardani et al. (2009) describe the lack of funds to acquire the required technology and equipment as a major barrier in most disasters. Other than the capital required, most authors interpreted the lack of capacity of both local and national institutions as another key barrier for effective $\mathrm{C} \& \mathrm{D}$ debris management. A lack of vulnerability assessments and risk assessments, a lack of environmental baseline data, a lack of technology know-how, and a lack of communication and coordination are some of the other areas highlighted (UNEP 2005c; UNDP 2005). Regardless of these constraints, Raufdeen (2009) indicates many benefits of C\&D debris management, such as the conservation of natural resources, the economical utilization of landfills, environmental and economic sustainability, the reduction of illegal and unauthorized dumping, reduced energy usage, cost recovery and financial incentives and compliance with policies, laws and regulations. Following this global overview, the next section will review $\mathrm{C} \& \mathrm{D}$ debris management in Sri Lanka. 


\section{Post-disaster C\&D debris management in Sri Lanka}

Sri Lanka is prone to natural disasters commonly caused by cycles of floods, cyclones, landslides, droughts and coastal erosion, with increasing loss to life and property during the past few decades (Jayawardane 2006; Karunasena et al. 2009). The devastation caused by the Asian Ocean Tsunami of 2004 took Sri Lanka by surprise, showing that Sri Lanka is also vulnerable to lowfrequency high-impact events causing extensive damage. Though there were several initiatives taken by the government and responsible authorities for disaster management, these were not adequate for a large scale disaster like the Asian Tsunami (Jayawardane 2006). A joint report by the government of Sri Lanka and joint development partners in December 2005 indicated that within a short period the Tsunami claimed 35,322 lives, injured 21,441 people, orphaned 1,500 children and left many families without family members, destroyed 78,199 homes and partially damaged 48,911 houses (Joint report 2005; United Nations-Occupancy Health Assessment 2005). In addition, two thirds of the country's coastline which was affected was where most industrial and commercial activities were situated, resulting in damaged roads, bridges, buildings, railway and other transport systems, ports and harbours, electricity and water supply systems, communication lines, markets, towns and private properties, estimated at a total loss of US\$ 105 million (4.5\% of GDP) (Asian Development Bank 2005; Jayasuriya et al. 2005; Jayawardane 2006; Karunasena et al. 2009).

Recognizing the magnitude and urgency, the President initially established three task forces for effective coordination: Task Force for Rescue and Relief (TAFRER), Task Force for Law and Order and Logistics (TAFLOL) and Task Force for Rebuilding the Nation (TAFREN) for effective coordination. A Centre for National Operations (CNO) was also established to coordinate the relief operations, and to gather and disseminate vital information (TAFREN 2005a, b; Jayawardane 2006). Thereafter, a legislative framework was established, in order to facilitate harmony, prosperity and dignity of human life through effective prevention and mitigation of disasters. The National Council for Disaster Management (NCDM) was established by the Disaster Management Act No. 13 of 2005 as a high-level interministerial body to provide direction to disaster risk management work of the country (DMC 2005, 2006; Jayawardane 2006; Karunasena et al. 2009). The Disaster Management Centre (DMC) is the lead agency for implementing activities related to all phases of Disaster Risk Management (DRM) in the country under the guidance of the Ministry of Disaster Management and Human Rights and National Council for Disaster Management (NCDM). These activities are carried out in coordination with relevant stakeholders in ministries, national and provincial level government and private agencies, civil society, non government organizations, community based organizations and communities. Fig. 1 illustrates the institutional framework of disaster management in Sri Lanka.
Disaster management operates at two levels: national and intermediate/local level. At national level, several divisions are established for resource allocation and prioritization of activities, budget allocation and monitoring of disaster management plans whereas all other disaster related activities are delegated to provincial and local levels (Refer Sri Lanka Disaster Management Act No. 13 of 2005).

Though national level polices for disaster management (Refer Disaster Management Act no 13 2005) and waste management (Refer National Environmental Act 1980) are available, it is noted that there are no provisions for disaster waste management. The Disaster Management Act only states that the disaster management council shall provide protection for the environment and maintain and develop affected areas (Disaster Management Act 2005) whereas the National Environmental Act addresses issues of general solid waste management (Raufdeen 2009). In Sri Lanka, C\&D waste is still classified as solid waste as there is no regulation specifically dealing with C\&D waste. Further, an in-depth review of the National Disaster Management Plan and the National Emergency Operation plan, which is in progress and would be enforceable in the near future, also have less provision for disaster waste management. However, during the post tsunami period, TAFREN, CEA and MENR (Ministry of Environment and Natural Resources) had jointly contributed to strengthening the national policy on the management of critical environmental issues such as the disposal of debris and solid waste. Further, they emphasize the importance of developing mandatory guidelines to ensure uniform practices (MENR 2005).

In addition, the United Nations Environment Protection report $(2005 \mathrm{c})$ also that debris were not properly disposed of, reused or managed in Sri Lanka (Pilapitiya et al. 2006; Peppiatt et al. 2001; UNEP 2005c; Pasche, Kelly 2005). Despite some regulations being introduced in the post tsunami period, these were not necessarily observed. For example, burning disaster waste along the coastline was regulated yet not observed and this could be because of a lack of preparedness for large scale disasters, lack of knowledge of government officials, and little or no input from those most severely affected. Moreover, most changes were not aligned with the social context of the impacted individuals (Shaw et al. 2003; UNEP 2005c). Hence, Jayawardane (2006) comments on the uncontrolled open dumping of contaminated waste and hazards which had significant negative public health and environmental impacts through contaminants leaking into soil and groundwater, increased vermin presence, negative odour and visual impacts following the tsunami. Further, according to the Europe Aid Co-operation Office (2006), C\&D debris is not recycled and reused at its optimum capacity in Sri Lanka, much of which is disposed of into landfill sites. In addition, Pasche and Kelly (2005) state that collected waste is often disposed of to "unplanned land fills in environmental sensitive sites". Accordingly the last option of waste processing has become the first option in Sri Lanka. However, there is evidence of recycling of $\mathrm{C} \& \mathrm{D}$ debris by individual homeowners who 


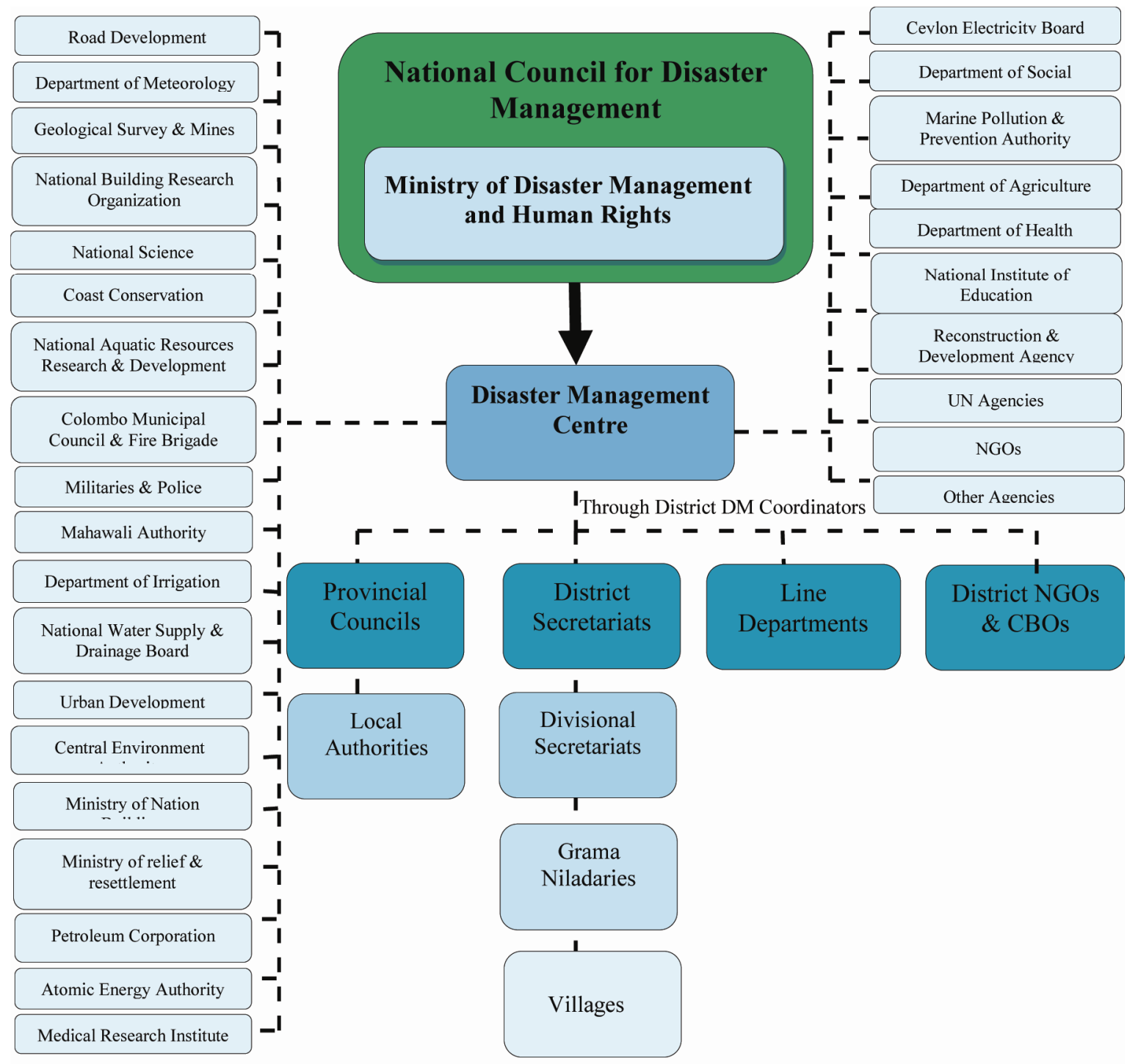

Fig. 1. The institutional framework for disaster management (DMC 2005, 2006)

attempted to re-use material in reconstruction and in cash for work programmes organized by CEA and NGOs, which were environmentally beneficial and helped with livelihood restoration (UNEP/UN-OCHA 2005; UNDP 2005; MENR 2005). Cash for work programmes for disaster debris management, removal of rubble, demolition of unsafe structures were also in evidence in the recent Haiti Earthquake in 2010 (Kelly 2010). Furthermore, risk assessments conducted in recent years indicate that most disaster waste management programmes conducted at local levels with collaboration of NGOs do not consistently meet current best practices due to the lack of readily available guidance, practical procedures and resources (UNDP 2005; UNEP 2005c; EC 2006; Martin 2007). In 2007, the National Disaster Management Committee of Sri Lanka also indicated that the capacity of Sri Lankan institutions is inadequate for successful disaster management (DMC 2009). All these literature findings are evidence for the prevailing ineffective post-disaster waste management practices which laid the foundation for further investigation of waste management strategies and challenges in Sri Lanka. The forthcoming section of the paper discusses the methodology adopted for the investigation of waste management strategies and challenges.

\section{Methodology}

A comprehensive literature review and documentary survey was conducted on post-disaster waste management to identify waste management strategies, models and challenges prevailing locally and globally.

Data was gathered from both national and local level institutes in Sri Lanka. Seven national institutes responsible for managing disasters were selected for the collection of data at national level covering both government and non-government organisations. Key professionals involved in post-disaster management were selected for interview from each institute.

At local level, six districts were chosen, based on the frequency and critical nature of the event over the last five years, in three categories: tsunami, floods, and landslides. Two most affected districts from each type were selected: 
- Tsunami:

Batticaloa and Galle districts;

- Floods:

Kaluthara and Gahampa districts;

- Landslides:

Interviewees were selected from top or middle management as well as field officers from both government and non-government organisations involved in postdisaster building waste management processes. Semistructured interviews were conducted at both levels to gather data as it facilitated an in depth analysis and the gathering of different views and opinions of respondents within the scope of the study.

Nvivo software was used to facilitate content analysis of the data. Relevant coding structures were prepared using software and analysed in order to determine practicing strategies and their challenges.

\section{Findings}

The findings of the interviews are discussed under two sub headings, national and local level as follows.

\subsection{Post-disaster waste management strategies: national level}

The findings reveal that national level government institutes, such as DMC, are involved with policy making, resource allocation, prioritization of activities, budget allocation and monitoring of disaster management plans, whereas all other related activities are delegated to local level (Refer Sri Lanka Disaster Management Act No.13 of 2005). Furthermore, at national level several divisions were established as Preparedness Planning, Training \& Public Awareness, Mitigation \& Technology, Emergency Operations, Multi Hazard Early Warning \& Dissemination, Risk Assessment \& Data Collection, Administration, Finance and Media while at intermediate level Districts Emergency Operation Units were established (DMC 2006). District Emergency Operation Units are responsible for preparing disaster preparedness and response plans for district, divisional and GN levels, capacity building of village level volunteers and conducting awareness programmes, etc. (DMC 2006). However, one key requirement is that provincial and local level plans shall be prepared in conformity with national level disaster plans. In this context, non-government institutes such as Sarvodaya are providing their knowledge and valuable ideas, gained through practical experience, to the government sector. Further, the findings reveal that in large scale disasters, C\&D debris have been managed with the collaboration of national and local level organisations. The role and functions of an organisation in disaster waste management varied based on the type of disaster. As a result, organisations did not take any responsibility over disaster waste and instead made contributions in their own specialist area. For example, while one organisation cleaned roads, another cleared debris from the seashore. Moreover, some organisations provided equipment and technical knowledge whereas others gave financial assistance. All interviewees stated that their particular institutions are not responsible for disaster waste management. One indicated "They are responsible only

for disaster management and generally involves in pre disaster events such as preparedness and mitigation". Some gave the opinion that waste management is a task of environmental organisations and local authorities. When the same question was posed to relevant environmental authorities, they stated "managing disaster waste is a major responsibility of disaster related organisations and they do not have special units for disaster waste management". The above demonstrates that there is no directly responsible regulatory body for disaster waste management in Sri Lanka.

Fig. 2 illustrates the coding structures used to analyse C\&D debris management strategies at both levels.

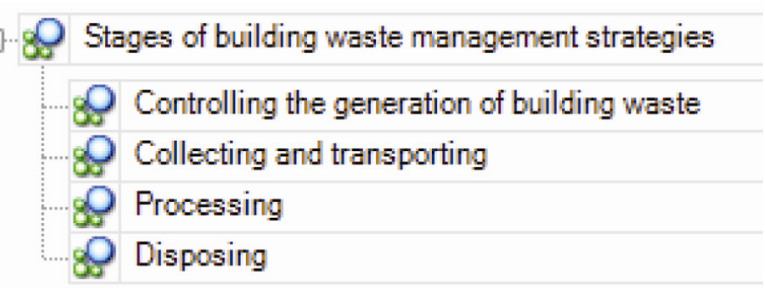

Fig. 2. Coding structure used for data analysis

In terms of controlling the generation of disaster waste, though pre planned strategies were non-existent, it was revealed that the government sector attempted to produce some guidelines or plans regarding disaster waste management such as rules pertaining to restrictions on burning and illegal dumping of disaster waste along the coastline during the post tsunami period, whereas the non government sector only implemented some practical measures to minimize impact. In terms of collecting and transporting disaster waste, both the government and nongovernment organisations actively participated, whereas the non-government sector more actively supplied manpower, technical support, equipment and vehicles. In terms of processing, there is no evidence that disaster waste has been processed in Sri Lanka, where the majority was disposed of in landfill. The only recycling plant that was implemented for construction waste management is in Galle (Raufdeen 2009), where the intention of processing post tsunami construction waste was not feasible due to delays in operation. Further, transporting from the dump site to the plant for recycling provided significantly lower benefits due to transportation costs. In terms of disposing of waste, both sectors confirmed land fill (marshy lands \& clay pits) and burning were adopted as disposal techniques.

Interviews revealed that a lack of capital and political wills were the key barriers impacting on implementing the proposed $C \& D$ debris management programmes in the recent past. One interviewee stated that, "after the tsunami a proposal came out to process building waste generated by the tsunami, but due to high initial costs, it could not be practiced'. Similarly, another stated that "It's better if the building waste can be recycled or reused. But the problem is the high cost of machines and power. If the cost of processing is less than the cost of original material, then it's beneficial to do so, especially for materials such as sand, metal and rubble". These 
comments proved that the lack of financial resources is a major problem in initiating building waste recycling projects in Sri Lanka. In addition, the lack of a single point of authority for disaster waste management is also significant, leading to various issues such as ad hoc programmes and poor coordination among authorities. This is further affected by lack of intellectual capacity such as lack of knowledge, expertise and training related to postdisaster management within relevant local authorities/ institutions. A significant fact is that government institutes fail to identify their capacities to guide others on assigning tasks and gain active participation. Further, most non-government institutes do not highlight these facts due to political influences, bureaucracy, demotivation and time consuming processes. All interviewees revealed that lack of community awareness has a major influence on proper disaster management. In addition, inadequate legal powers and lack of operational powers are identified as major capacity gaps at national level. This is differentiated from the point of view of nongovernment organisations that only have a social responsibility or public interest. The next section will discuss the findings related to $C \& D$ debris management at local level.

\subsection{Post-disaster waste management strategies: local level}

As illustrated in Fig. 1, Local Authorities: Municipal Councils, Urban Councils and Pradeshiya Sabas are responsible for the management of disaster waste at local level. Non existence of pre planned waste management strategies are evident at local level where open dumping and land filling were used as common waste management practices. Solid waste management rules of local government agencies were applied for management of C\&D disaster waste such as those of Municipal Councils Ordinance (section 129,130,131), Urban Councils Ordinance (section 118,119,120) and Pradeshiya Sabhas Act No. 15 of 1987, section 93,94) (Raufdeen 2009). Further, all districts revealed an ability to manage disaster waste on their own in the case of small scale disasters such as floods and landslides, with their own capacities except in the case of a large scale disaster such as a tsunami.

Waste management practices reveal that in most districts, the initial step was to clear access routes to collect waste. In Batticaloa, the relevant authority separated building waste prior to dumping, whereas in other districts waste was dumped without separation. In terms of processing, in almost all the districts, private owners reused usable waste and there was no $\mathrm{C} \& \mathrm{D}$ debris recycling process. However, in Batticaloa a small proportion of building waste was reused for temporary huts whereas in Galle a recycling plant was initiated with the intention of collecting, sorting and recycling or reusing C\&D waste as road construction material. Specifically, the COWAM (Construction Waste Management) project within the EU-ASIA PRO ECO II B Post Tsunami Programme was initiated to manage $C \& D$ waste in Sri Lanka. The aim was to provide the Galle area with practical solutions for implementing a sustainable $C \& D$ waste management programme and for it to become a model for all other local authorities in the country. This would involve preparation of guides for the public on waste management, control illegal dumping, give legal support, select suitable places for gathering waste, supply human and physical resources, implement rules and regulations and reduce the use of virgin construction material. In addition, research on waste management, testing construction and recycled materials and sharing knowledge of professionals are also identified achievements of this project. Furthermore, the Amapara and Hambanthaota districts initiated projects targeting recycling of plastic items and composting of degradable components. In terms of disposal, Batticaloa used building waste to fill damaged roads and low level ground whereas in Galle waste was transported from temporary dumping places to permanent dumping places located within a $5 \mathrm{~km}$ distance of Galle town. In Kalutara, all types of waste was collected and dumped directly in dumping yards, and in Gampaha a small proportion of waste was used to fill damaged roads and the rest was dumped at a dumping yard. In Nuwara-Eliya disposal of waste was done by filling lakes, sides of roads and covering up dumped garbage. In Kandy all waste was dumped at garbage dumping yards.

A lack of heavy vehicles and labour impacted all stages of the disaster waste management processes at local levels. In Batticaloa, disaster waste separation was mainly done by non- government organisations, which was then stolen by third parties, which in turn was a critical issue visible in that district. In Galle, the main issues were identifying temporary dumping yards and providing clean drinking water. However protests from temporary dumping yard owners and the relevant authorities further aggravated the issues. For example, one stated that "the major problem is to find dumping sites. For each selected site, the dwellers from that area start to protest against the selected site". Further, the recycling plant took a long time to put into operation and that drastically reduced its effectiveness. In Kalutara, the requirement for an alternative dumping ground and malpractices related to reusable waste were identified as critical issues. In NuwaraEliya, its geographical location and protests against the municipal council for disposing of waste in forest areas were the major issues. The next section of this paper discusses the gaps identified in post-disaster waste management in the Sri Lankan context.

\section{Discussion}

The findings revealed that the strategies used for postdisaster waste management varied in terms of the type of disaster, nature and impact. When considering floods and landslides, which can be considered to be small scale disasters, the issues that arose were mostly similar. The most common issues are a lack of awareness among the community, a lack of technology, physical assets and finance. Ardani et al. (2009) also highlighted the lack of funds to acquire the required technology and equipment as a major barrier, identified in post Hurricane Katrina in the United States. This shows common issues are prevailing in spite of whether the country is developed or devel- 
oping. In addition, the absence of pre-planning, a lack of coordination among organisations, a lack of innovation of technology and improper post-disaster waste management mechanisms further aggravated poor disaster waste management practices. One interviewee also accepted that "even the trained volunteers are useless without a proper plan in dealing with disaster waste".

The lack of authority to function is another common issue which impacts bottom level government organisations as they have not been given enough power to initiate or implement any work without coordinating with top level departments. Other than these, the lack of professionals, the lack of coordination among service providers, the lack of research, unavailability of long term plans and frail rules and regulations affect each organisation. This is mainly affected by improper guidance of national level organisations and the absence of local frameworks for post-disaster waste management. This is also influenced by the existing institutional framework for solid waste management in a country where the authority is vested in independent provincial and local authorities that tend to work in isolation. Further, this is aggravated by political mismatches visible among provincial \& local authorities who may have been elected by different political parties. In spite of this, general solid waste management rules and regulations prevailing in Sri Lanka are not properly implemented due to an absence of penalties or incentives.

Thus, this study helped to identify the gaps of postdisaster waste management in Sri Lanka that need to be addressed for effective C\&D debris management and aid future resilience. Haigh and Amaratunga (2010) emphasise the importance of the concept of resilience in the context of disaster management. In this context, the following section of this paper briefly explains the proposed recommendations towards resilience in the context of post-disaster waste management.

\section{Way forward}

Investigation into post-disaster waste management strategies revealed the following gaps in Sri Lanka:

- a lack of single responsible authority including a hierarchical structure for disaster waste management;

- a lack of a pre-planned framework of rules and regulations that are enforceable by statute and which are mandatory. Specifically, the presence of an environmentally sound post-disaster waste management framework;

- capacity constraints such as technology know how, funds, physical resources, etc.;

- management constraints such as communication and coordination among involved parties, poor government encouragement and poor utilisation of resources;

- a lack of awareness;

- applicability of continuity and sustainable approaches;

- a lack of research and development.
These gaps concluded that though the government institutions encompass certain legal powers to carry out post-disaster waste management, it has not happened effectively and efficiently. Conversely, the non-government organisations do not possess any legal power to implement their own projects, whereas most of them are willing to provide their financial and other technical support on managing disaster debris. Thus, it is evident that the availability of a sound framework will be worked out successfully through the support of the non-government sector. Accordingly, this paper proposes a framework for post-disaster C\&D debris management in Sri Lanka.

Fig. 3 illustrates the framework prepared which focuses on disasters like tsunamis, floods, landslides and earthquakes that have the highest possibility of generating a significant quantity of $\mathrm{C} \& \mathrm{D}$ waste.

The initial step will be the establishment of an organisational hierarchy, to assign functions and duties. Accordingly, with collaboration of all stakeholders, a council for disaster waste management needs to be appointed under the Ministry of Disaster Management and Human Rights with relevant committees. Then, each committee needs to start implementation of all other activities in the framework. The action plan and all other programmes are set up in the preparedness and planning stage. Consequently an early warning and communication system also needs to be established. It may include a method of communicating from top to bottom of the organisational hierarchy to maintain an efficient level of coordination.

At the post-disaster stage, initial response is the primary stage that requires the initial clearing of debris just after an emergency situation and after that the secondary operation can be initiated. The prepared action plan of C\&D waste management can then be used depending on the type and size of disaster. One interviewee pointed out that "each local authority in each area should conduct analysis programmes to identify the most vulnerable disasters in that area and most probable types of waste which can be generated depending on the nature of buildings and industries in that area. Then they have to prepare a plan to manage that waste in a situation of a disaster. The legal enforceability and funding of the aforesaid action plan needs to be provided for by the respective committees (Refer to Appendix A for proposed action plan for $C \& D$ debris management). On a par with these developments, a change of attitude in government institutes should be encouraged in order to gain maximum utility from in-house NGOs by sharing responsibilities, assigning a considerable amount of liabilities and getting active commitment.

\section{Conclusions}

Whilst it is accepted that human loss is the true tragedy of disasters, the destruction of buildings and infrastructure can also be considered as having a significant impact on an economy as well as on an ecosystem. Ruined buildings and infrastructure generates a tremendous quantity of debris including rubble, concrete, bricks, steel and timber that places an additional burden on a community. Thus, in 


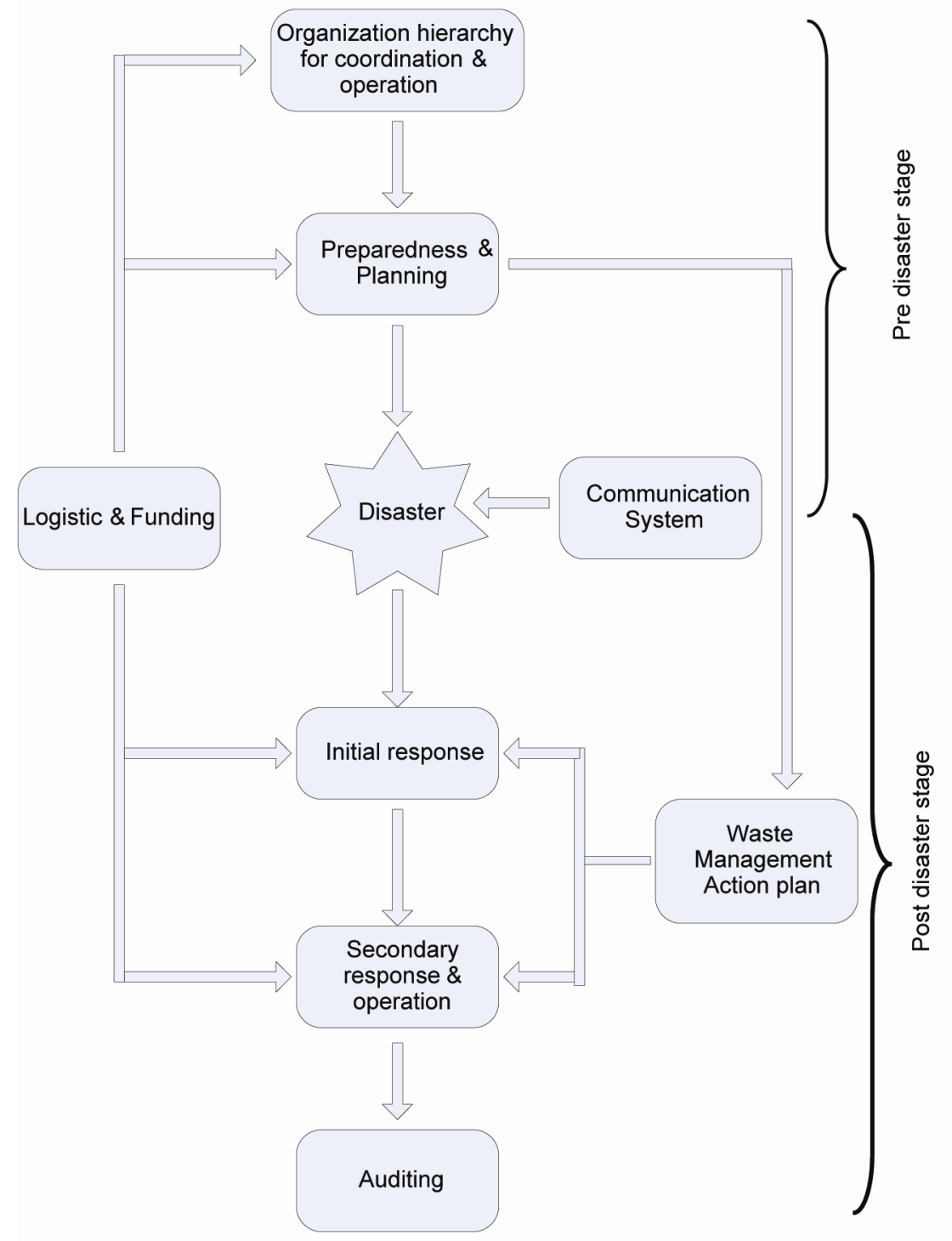

Fig. 3. Framework for post-disaster C\&D debris management

rebuilding, the process should encourage incorporation of building waste reduction, reusing and recycling strategies. Sri Lanka is also identified as a disaster prone country, experiencing a variety of disasters with immense damage caused, such as the Asian Tsunami of 2004. Besides deaths and injuries, building and infrastructure damage causes tremendous quantities of waste. Hence, this paper has identified post-disaster waste management strategies adopted in Sri Lanka during the recent past. Data was collected using semi-structured interviews at both national and local levels and content analysis used as the analysis technique.

The findings revealed poor waste management practices such as open dumping and burning, which was further aggravated by a lack of enforceable legislation, non-availability of an institutional framework, a lack of coordination and communication, non-availability of district and divisional contingency plans, a lack of political will and inadequate resources including finance, equipment and labour. In conclusion, though government institutions encompass certain legal powers to carry out post-disaster building waste management, these have not been implemented and enforced effectively. Thus, a framework for post-disaster C\&D waste management is proposed, with a centralized responsible body to manage and coordinate disaster waste management operations, with effective procedures to deal with $C \& D$ debris in Sri Lanka.

\section{References}

Ardani, K. B.; Reith, C. C.; Donlan, C. J. 2009. Harnessing catastrophe to promote resource recovery and ecoindustrial development, Journal of Industrial Ecology 13(4): 579-591.

http://dx.doi.org/10.1111/j.1530-9290.2009.00136.x

Asian Development Bank. 2005. An initial assessment of the impact of the earthquake and tsunami of $25^{\text {th }}$ December, 2004 on South and Southeast Asia. Asian Development Bank Report, Manila, Phillipines. 10 p.

Barnett, J. 2007. The geopolitics of climate change, Geography Compass 1(6): 1361-1375.

http://dx.doi.org/10.1111/j.1749-8198.2007.00066.x 
Baycan, F. 2004. Emergency planning for disaster waste: A proposal based on the experience of the Marmara Earthquake in Turkey, in The International Conference and Student Competition on post-disaster reconstruction "Planning for reconstruction", 22-23 April, 2004, Coventry, UK. 6 p.

Baycan, F.; Petersen, M. 2002. Disaster waste managementC\&D waste, in The Annual Conference of the International Solid Waste Association, 8-12 July, 2002, Istanbul, Turkey, 117-125.

Blakely, E. 2007. Collaborating to build communities of opportunity, in The Roosevelt Institute Symposium, 31 November, 2007, Louisiana, New Orleans.

Booth, W. 2010. Haiti faces colossal and costly cleanup before it can rebuild, The Washington Post, 7 March, 2010. 2 p.

Brown, C.; Mike, M.; Seville, E. 2010. Waste management as a "Lifeline"? A New Zealand case study analysis, International Journal of Disaster Resilience in the Built Environment 1(2): 192-206. http://dx.doi.org/10.1108/17595901011056640

Brown, C.; Milke, M. W. 2009. Planning for disaster debris management, in The Waste MINZ 21st Annual Conference, 14-16 October, 2009, Christchurch, New Zealand. 9 p.

Brown, C.; Milke, M.; Seville, E.; Giovinazzi, S. 2010. Disaster waste management on the road to recovery: L'Aquila Earthquake case study, in The 14th European Conference on Earthquake Engineering (14ECEE), 30 August 3 September, 2010, Ohrid, Macedonia, 8 p.

California code of regulation, Title 14 [cited 10 May 2010]. Available from Internet: < http://www.calrecycle.ca.gov/ Laws/regulations/title14/ch3a6.htm>.

Davis, I. 1978. Shelter after disaster. Oxford: Oxford Polytechnic Press. 127 p.

Disaster Management Act No 13 of 2005, in Gazette of the Democratic Socialist Republic of Sri Lanka, Supplement to Part II, May 13, 2005. Colombo: Government Publications Bureau. $10 \mathrm{p}$.

Disaster Management Centre (DMC). 2005. Towards a Safer Sri Lanka. Road Map for Disaster Risk Management. Vol. 1. Colombo: Disaster Management Centre (DMC). 101 p.

Disaster Management Centre (DMC). 2006. Towards a Safer Sri Lanka. Road Map for Disaster Risk Management. Vol. 2. Colombo: Disaster Management Centre (DMC). $307 \mathrm{p}$.

Disaster Management Centre (DMC). 2009. Newsletter (1st Quarter). Working together for Disaster Risk Reduction. Colombo: Disaster Management Centre (DMC). 8 p.

Eerland, D. W. 1995. Experience with the construction and demolition waste recycling in the Nether lands - Its application to earthquake waste recycling in Kobe, in International Symposium on Earthquake Waste, 12-13 June, 1995, Osaka, Japan. Shiga: UNEP, 72-85.

Environmental Protection Agency (EPA). 1995. Characterization of building related construction and demolition debris in the United States, 530-R-98-010. EPA, USA. 102 p.

Environmental Protection Agency (EPA). 2008. Planning for Natural Disaster Debris [cited 5 May 2010]. Available from Internet: <http://wwwepagov/CDmaterials/pubs/ pnddpdf $>$.

Europe Aid Co-operation Office. 2006. Construction waste management in Sri Lanka [cited 5 May 2010]. Available from Internet: <http://wwwcowam-project.org $>$.
European Commission. 2006. Progress report on Post Tsunami rehabilitation and reconstruction programme [cited 5 May 2010]. Available from Internet:

$<$ http://eceuropaeu/comm/world/tsunami/index.html $>$.

General Accounting Office. 2008. General Accounting Office reports \& testimony. Hurricane Katrina: Continuing debris removal and disposal issues, GAO-08-985R. Washington, DC: GAO. 39 p.

Haigh, R.; Amaratunga, D. 2010. An integrative review of the built environment discipline's role in the development of society's resilience to disasters, International Journal of Disaster Resilience in the Built Environment 1(1): 11-24. http://dx.doi.org/10.1108/17595901011026454

Helmer, D.; Hihorst, D. 2006. Natural disasters and climate change, Disasters 30(1): 1-4. http://dx.doi.org/10.1111/j.1467-9523.2006.00302.x

Jayasuriya, S.; Steele, P.; Weerokon, D. 2005. Post Tsunami Recovery: Issues and Challenges in Sri Lanka [cited 5 May 2010]. Available from Internet:

$<$ http://.www.ipslk/news/newsarchive/2005/01122005_p tsun/tsunami_recovery.pdf $>$.

Jayawardane, A. K. W. 2006. Recent Tsunami Disaster Stricken to Sri Lanka and Recovery, in International Seminar on Risk Management for Roads, Organised by PIARC and Ministry of Transport, 26-28 April, 2006, Vietnam.

Joint Report. 2005. Sri Lanka Post Tsunami Recovery and Reconstruction - progress challenges and way forward, Joint Report of the Government of Sri Lanka and Development Partners, Colombo: Ministry of Finance and Planning. $44 \mathrm{p}$.

Karunasena, G.; Amaratunga, D.; Haigh, R.; Lill, I. 2009. Postdisaster Waste Management Strategies in Developing Countries: Case of Sri Lanka, International Journal of Strategic Property Management 13(2): 173-191. http://dx.doi.org/10.3846/1648-715X.2009.13.171-190

Kelly, C. 2010. Rapid Environmental impact Assessment: Haiti Earthquake-January 12, 2010 [cited 5 May 2010]. Available from Internet: $<$ http://www.smtn.org $>$.

Kobayashi, Y. 1995. Disasters and the problems of waste, in The International Symposium on Earthquake Waste, 1213 June, 1995, Osaka Shiga, Japan, 6-13.

Kuramoto, N. 1996. The actual state of damage and measures undertaken in Hyogo Prefecture, in Proc. of Earthquake Waste Symposium, 12-13 June, 1995, Osaka, Japan. UNEP Technical Publication Series (2).

Lauritzen, E. K. 1998. Emergency construction waste management, Safety Science 30(1-2): 45-53 http://dx.doi.org/10.1016/S0925-7535(98)00032-0

Lindell, M. L.; Prater, C. S. 2003. Assessing community impacts of natural disasters, Natural Hazards Review 4(4): $176-185$.

http://dx.doi.org/10.1061/(ASCE)1527-6988(2003)4:4(176)

Luther, L. 2008. Managing Disaster Debris: Overview of Regulatory Requirements Agency Roles and Selected Challenges [cited 5 May 2010]. Available from Internet: $<$ http://wikileaksorg/wiki/CRS-RL34576>.

Martin, N. 2007. The Asian Tsunami: An urgent case for improved government information systems and management, Disaster Prevention and Management 16(2): 188-200. http://dx.doi.org/10.1108/09653560710739513

Ministry of Environment and Natural Resources (MENR). 2005. Post Tsunami Environmental Assessment in Sri Lanka: Recommendations for Environmental Recovery, 
Ministry of Environment and Natural Resources. Sri Lanka: Colombo. 87 p.

National Environmental Act No 47. Colombo: Government publications bureau, $1980.11 \mathrm{p}$.

Ofori, G. 2002. Construction Industry Development for Disaster Prevention and Response [cited 24 February 2010]. Available from Internet: <http://www.grif.umontreal.ca/pages/ i-rec\%20papers/ofori.pdf $>$.

Oliver-Smith, A. 1990. Post disaster housing reconstruction and social inequality: A challenge to policy and practice, Disasters 14(1): 7-19.

http://dx.doi.org/10.1111/j.1467-7717.1990.tb00968.x

Pasche, A.; Kelly, C. 2005. Concept Summary: Improving the disposal of Tsunami generated waste. Sri Lanka: UNDAC. 22 p.

Pelling, M.; Ozerdem, A.; Barakat, S. 2002. The macro economic impact of disasters, Progress in Development Studies 2(4): 283-305.

http://dx.doi.org/10.1191/1464993402ps042ra

Peppiatt, D.; Mitchell, J.; Holzmann, P. 2001. Cash transfers in Emergencies: Evaluating Benefits and Assessing Risks, HPN Network paper No 35. London: Overseas Development Institute. 24 p.

Petersen, M. 2004. Restoring waste management following disasters, in International Conference on Post-Disaster Reconstruction, 22-23 April, 2004, UK Coventry: IF Research group.

Pike, J. 2007. Spending federal disaster aid comparing the process and priorities in Louisiana and Mississippi in the wake of Hurricanes Katrina and Rita. Baton Rouge LA: Nelson A Rockefeller Institute of Government and the Public Affairs Research Council of Louisiana. 49 p.

Pilapitiya, S.; Vidanaarachchi, C.; Yuen, S. 2006. Effects of the tsunami on waste management in Sri Lanka, Waste Management 26(2): 107-109. http://dx.doi.org/10.1016/j.wasman.2005.10.004

Rafee, N.; Karbassi, A. R.; Nouri, J.; Safari, E.; Mehrdadi, M. 2008. Strategic management of municipal debris aftermath of an earthquake, International Journal of Environmental Research 2(2): 205-214.

Raufdeen, R. 2009. Construction Waste Management: Current status and challenges in Sri Lanka. Galle: COWAM centre. $80 \mathrm{p}$.

Salehyan, I. 2008. From climate change to conflict? No consensus yet, Journal of Peace Research 45(3): 315-326. http://dx.doi.org/10.1177/0022343308088812

Shaw, R. 2006. Indian Ocean tsunami and aftermath. Need for environment-disaster synergy in the reconstruction process, Disaster Prevention and Management 15(1): 5-20. http://dx.doi.org/10.1108/09653560610654202

Shaw, R.; Goda, K. 2004. From disaster to sustainable civil society: the Kobe experience, Disaster 28(1): 16-40. http://dx.doi.org/10.1111/j.0361-3666.2004.00241.x
Shaw, R.; Gupta, M., Sharma, A. 2003. Community recovery and its sustainability: lessons from Gujarat earthquake in India, The Australian Journal of Emergency Management 18(2): 28-34.

Sri Lanka Disaster Management Act No. 13. Parliament of the Democratic Socialist Republic of Sri Lanka, 2005. 18 p.

Srinivas, H.; Nakagawa, Y. 2008. Environmental implications for disaster preparedness: lessons Learnt from the Indian Ocean Tsunami, Journal of Environmental Management 89(1): 4-13. http://dx.doi.org/10.1016/j.jenvman.2007.01.054

Task Force for Rebuilding the Nation (TAFREN). 2005a. Recovering from Tsunami: A report on the progress of the post-tsunami recovery of Sri Lanka and the role of TAFREN in the recovery effort. Colombo: The Task Force for Rebuilding the Nation, Sri Lanka, November 2005. $22 \mathrm{p}$.

Task Force for Rebuilding the Nation (TAFREN). 2005b. District wise post tsunami rehabilitation and reconstruction projects: Rebuilding Sri Lanka, Post Tsunami Recovery and Reconstruction strategy Update of Part II - Progress made and problems encountered. Colombo: The Task Force for Rebuilding the Nation, Sri Lanka. 25 p.

Taylor, A. 2008. Sichuan's earthquake, six months later, The Boston Globe [cited 5 May 2010]. Available from Internet: <http://www.boston.com>.

United Nation Development Programme (UNDP). 2005. PostTsunami Recovery and Reconstruction Strategy. Sri Lanka. $55 \mathrm{p}$.

United Nation Environment Programme (UNEP). 2005a. After the tsunami: rapid environmental assessment. Nairobi: United Nations Environment Programme. 140 p.

United Nation Environment Programme (UNEP). 2005b. Report of the workshop on disaster waste management. Workshop organized by UNEP and BAPEDDALDA, July, 2005, Indonesia: Banda Aceh. 22 p.

United Nation Environment Programme (UNEP). 2005c. Sri Lanka post tsunami environmental assessment. Geneva: UNEP (DEP/0758/GE). 15 p.

United Nation Environment Programme /United Nation-Office for the Coordination of Humanitarian Affairs Environment Unit. 2005. Indian Ocean tsunami Disaster of December 2004: UNDAC rapid environmental assessment in the democratic socialist republic of Sri Lanka. Switzerland: Joint UNEP/UN-OCHA Environment Unit. 12 p.

United Nations-Occupancy Health Assessment. 2005. Indonesia, Maldives, Sri Lanka: earthquake and tsunami. OCHA situation report No. 19, New York, USA. 32 p.

Zeilinga de Boer, J.; Sanders, D. T. 2004. Earthquakes in Human History: the Far-reaching Effects of Seismic Disruptions. Princeton University Press Princeton, NJ. 264 p. 


\section{Appendix A: Action plan for C\&D debris management}

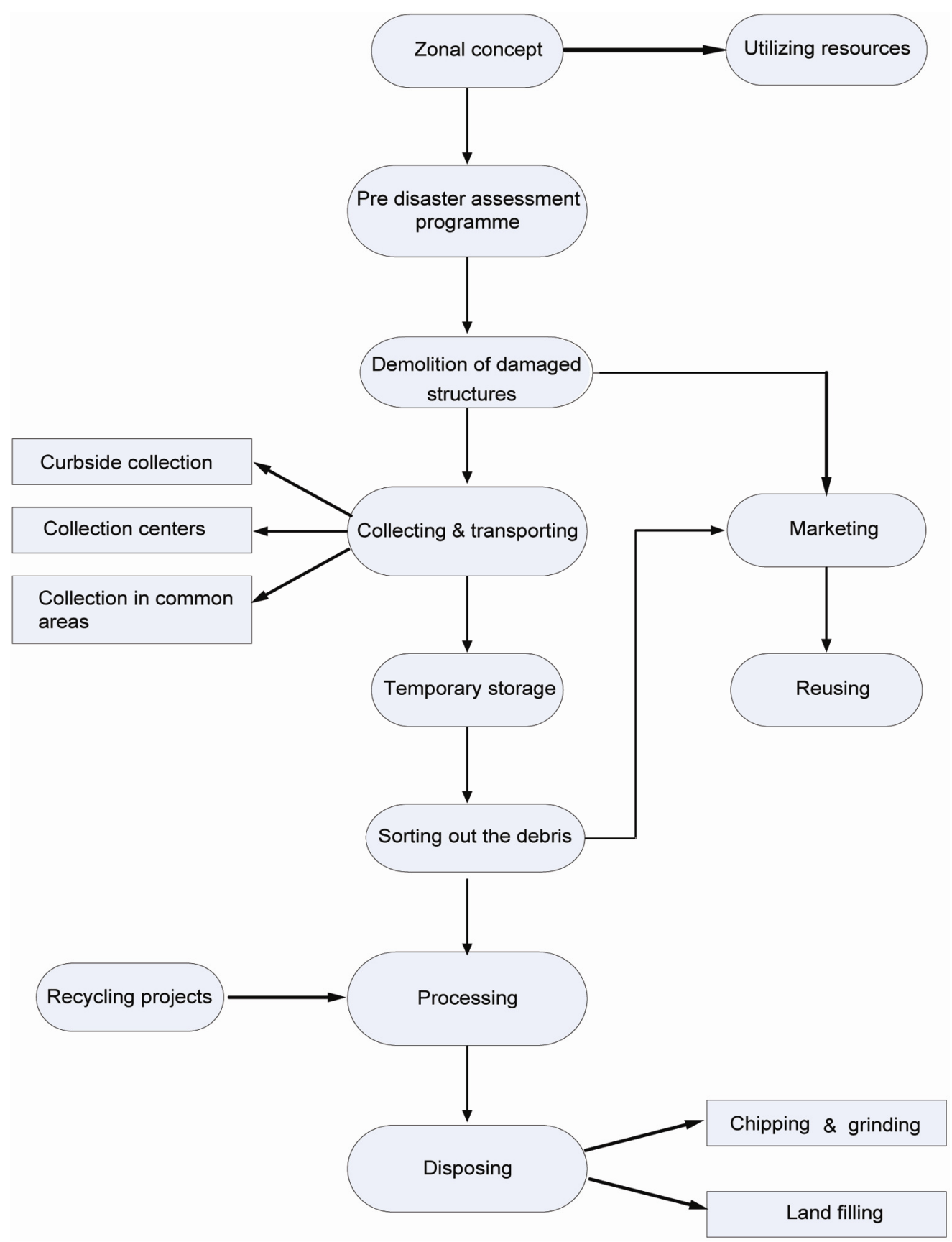

Action plan

- Divide the country into a number of zones in order to utilize resources to a maximum;

- Conduct pre disaster assessment programmes in each area to identify the most vulnerable disasters prior to preparing the action plan;

- Demolish the partially damaged buildings and separate the usable building materials for reuse;
- Collect and temporarily store the debris for the sorting out process prior to recycling;

- Initiate recycling projects and recycle all possible materials for reuse and marketing;

- Dispose of all unfeasible materials into pre designated dumping sites. 
Gayani Inoka KARUNASENA. Senior lecturer attached to Department of Building Economics, University of Moratuwa, Sri Lanaka. She is a member of CIB, working group TG63-Disasters and the built environment. Her research interests include the disaster management, capacity building and construction information technology.

Dilanthi AMARATUNGA. Professor of Disaster Management at the University of Salford, UK where she leads the University's Centre for Disaster Resilience, responsible for supporting research on disaster management portfolios. She is also the Associate Head of International Development for the School of the Built Environment. Her research interests include post disaster reconstruction including conflict mitigation, gender and projection; Capability and Capacity building in managing disasters; Socio-economic measures for conflict affected re-construction and women in construction. She is the Co-Editor of International Journal of Disaster Resilience in the Built Environment. She has presented widely at International conferences, has led international disaster management workshops and seminars and working actively with the UN. Dilanthi is a member of the Royal Institution of Chartered Surveyor s (RICS). As a member of the RICS, she leads several of their disaster management initiatives. She has supervised and supported a wide range of Postgraduate Research students and to date she has produced over two hundred publications, refereed papers and reports, and has made a large number of presentations in around 25 countries. Dilanthi's profile can be found at www.dilanthiamaratunga.net.

Richard HAIGH. Senior Lecturer at the Centre for Disaster Resilience, which is based in the School of the Built Environment, University of Salford, UK. He is Programme Director of the School's Disaster Mitigation and Reconstruction Masters programme and also Joint Editor of the International Journal of Disaster Resilience in the Built Environment. Richard undertakes research related to the application of disaster risk reduction in the built environment. His main research interests include the reintegration and rehabilitation of conflict affected communities in Sri Lanka, and corporate social responsibility in disaster risk reduction. He is working closely with local government and major stakeholders to reduce the level of disaster risk in the Sri Lankan District of Batticaloa as part of the UNISDR's Resilient Cities campaign. He was previously Joint Coordinator of CIB's Task Group 63 on Disasters and the Built Environment (2006-2010) and Co-Chair of the 2008 Building Education and Research Conference, held in Kandalama, Sri Lanka. The conference focused on the built environment field's role in developing a society's resilience to disasters. A detailed list of Richard's publications and activities can be found at www.richardhaigh.info. 